\title{
Commentary on History of Ecological Culture
}

\section{Sherzod Yunusovich Salimov*}

Scientific and Enlightenment Complex named after the First President the Republic of Uzbekistan Islam Karimov, Tashkent, Uzbekistan

*Corresponding author: Salimov YS, Scientific Researcher, Scientific and Enlightenment Complex named after the First President the Republic of Uzbekistan Islam Karimov, Tashkent, Uzbekistan, Tel: +99893-537-27-06; E-mail: zippt@mail.ru

Received date: 14 June, 2018; Accepted date: 27 June, 2018; Published date: 3 July, 2018

Copyright: @ 2018 Salimov SY. This is an open-access article distributed under the terms of the Creative Commons Attribution License, which permits unrestricted use, distribution, and reproduction in any medium, provided the original author and source are credited.

\section{Abstract}

The history and variety of theories of the development stages of ecological culture are discussed in this article.

Keywords Ecology; Ecological culture; Environment; Development; Stages; Period; Human; Nature; Scientist; Relation; Relationship; Society; Flora and fauna

\section{Short Commentary on Ecological Culture}

Despite the fact that, the term "Ecology" came into the science in 1866, the concept of ecology and ideas related to it appeared a long time ago. Scientists both from Uzbekistan and other countries investigated the issues related to the history and evolution of ecological culture development and as a result they have made certain theoretical and practical conclusions. For instance, U.G. Saidova divided the culturalizing level of relation between society and nature into three stages: first stage is developing nature coincides with the early period of human development, that times human being used the readymade things of nature; the second stage is the period when human used not only ready products of nature, but he started to produce certain things, artificial materials on his own; the third stage started after World War II and includes the period till present day [1].

We think that it is appropriate to make broader approach on above given idea about dividing culturalzing level of relation between society and nature into three stages, because a number of scientists have different attitudes about this issue. For instance, Belarus scientist Sergeychuk divides the collection of knowledge on ecology into 5 stages Thus, S.A. Sergeychuk divides the history of ecological development into five stages in his book "The stages of ecological development" [2] Scientist presents the first stage dividing it into four periods: first period goes to VII-centuries B.C. with the Egyptian, Indian, Chinese and European scientists assumptions about the mutual relationship of human and outer world, for instance "in 6-8 years the use of wheat, later the use of rice, corn and citrus plants"; second period is the knowledge about relation of flora and fauna with outer world developed by the ancient Greek and Roman thinkers 2250 years ago.

For example, Aristotle proved the classification of organisms in his work, where he wrote about more than 500 animal species and their way of life. His follower Georphast Ezorishi ( 370-285 B.C.) in his work "Research about plants" wrote that the shape and growth of plants are related to the structure and temperature of soil; the third period covers middle ages and according to the scientist's opinion, due to dogmatism and scholasticism of middle ages, ecology did not develop well. But in XIII century Albert the Great (1206-1280) wrote "Treatise about plants" and in XIV century for the first time it was mentioned that there were botanic gardens in Italy. The fourth renaissance period described as the era of intensive development of natural sciences, especially, development of scientific researches, expeditions in the sphere of botany and ecology, new geographic inventions and the collection of data about new lands.

Accepting all above mentioned thoughts, we would like to emphasise on scientists' research of Central Asia on this issue as there were some views and information concerning ecology in society development in the historical process. For instance, great scholar Muhammad Khorazmiy (783-850) in his work named "Kitob surat alarz" wrote that oceans of the world, continents, forests, deserts, mountains, rivers, seas and lakes and others considered to be the main wealth of the Earth. Abu Nasr Farobiy (870-910) wrote about human and animals body structure, their features and tasks, similarities and differences in his works. According to Abu Rayhon Beruniy (973-1048) human can learn subsistence properly and scientifically, only when he follows all the rules of nature. In his works, the biological features of animals, their expansion, reproduction and importance in agriculture are deeply investigated. Zahiriddin Muhammad Babur (1483-1530) described the nature, wealth, people, customs, traditions, flora and fauna of countries that he had seen in his work "Boburnoma". Thus, scientists of Central Asia played a big role in collecting and developing information about ecology in middle ages.

Sergeychuk explains the other stages of ecological development in his work as follows: second stage is charecterised as biological subject and ecological knowledge about the geography of plants and animals; the third stage is adapting of plants ecology and animals ecology to organisms living conditions and the formation of ecology as a science; 4 -stage is the theoretical base of protection and exploitation of ecology and nature; formation of ecology as a general biological subject (20-60th of XX century); finally the 5-stage is the separation and development of global ecology within anthropological (human) ecology and it started since 60th of XX century and continues till present days [2]. Above given ideas about 5 stages of formation and development of environmental knowledge and ecological culture show that this issue was widely approached. Though, there is a certain discrepancy among scholars' scientific approach, but still these ideas are very close to each other in terms of content. For instance, the history of ecological development is described in the book "History of ecology and modern state" as follows: the first stage of origin of ecology as a science took place around 60th of XIX century, 2-stage is the formation of ecology as independent science covers the period from 60th of XIX century to 50th of XX century; finally the third stage 
Page 2 of 2

is the present stage of ecology that is converted into a complex science that reflects protection of environment and nature by human. It has started since 50th of XX century till present days [3]. American scientist Donald Worster in his book "Nature's Economy: A History of Ecological Ideas" divided modern ecology into six parts. The First Part is oriented to Gilbert White and Carolos Linnaeus and number of others whose ideas helped to launch new science about ecology in the eighteenth century. Second Part is devoted to Henry David Thoreau, whose cluster of ideas still active today. The mid-nineteenth-century work of Charles Darwin and his theories about ecology considered as Part Three. Part Four brings into twentieth century, where the science of ecology came to have immense public importance in some parts of America. In Part Five Alfred North Whitehead and the background of Aldo Leopold's ecology-based land ethics were discussed. Finally, in the Last Part, the author described the World War Two period where ecology became political movement [4].

It is clear that, each scholar investigated the history of ecology and development of environmental culture in their own way. Considering above mentioned ideas, we also would like to define the history, genesis and evolution of ecology and development of environmental culture, relying on our research result. According to our research there are four periods of the development of ecological culture. The first stage starts from ancient period till 60th of XIX century, unlike Sergeychuk's suggestion to divide it into four periods, we suggest to divide it into three periods: the First period is the adaptation of ancient people to the environment, generally to the nature "Kaltaminor culture", that is IV and III century B.C. late Stone Age and Neolithic period when people learned natural rules and observed environment, learned to satisfy their material needs, imagination and views about self-protection comprised primitive consciousness; the Second period of formation ecological culture as far as we concern, related with the formation of initial religion. If animism indicates that human and everything in universe have life and spirit, totemism designates that human has relationship with one of the plants or animals. Magic actions mean to prevent events of different forms that are against human being. Taboo (prohibition) is used in relations of human with natural phenomena, flora and fauna and as a result peculiar traditions and ceremonies are formed. An English ethnologist and religious scholar Fraser wrote that, "Taboo is used not only in relation with primitive activity, but also with any kind of animated and inanimate thing of nature", even "it is used with types of food". The case that primitive man felt his relation with environment, earth, water and air, especially, that he did it with intellect helped to form intellectual culture for that time people. As a result, along with development of individual and social mind, the level of ecological culture also improved. The Third period presents the better development of ecological culture because of national and world religions formation and the observance of their sacred scripture. For example, the first world religion "Avesta" (Zoroastrism) was the basis of enriching environmental culture within millennium as it sanctified four main substance of world philosophy: soil, water, air and fire. Moreover, in Buddhism, Christianity and especially in different sources of human religion the issues of development of ecological culture are given and people followed them throughout centuries. The Fourth period actually started in 50th after the World War II and it exists until today. Present days, almost all countries in the world paid special attention to environmental issues. In particular, United Nations 10 years Conference on the Human Environment on 5th June 1982, "Greens conference" in Stockholm, Europe in 1987, Kyoto Protocol United Nations Framework Convention on Climate Change in France, Kyoto Protocol in Bucharest; in order to provide security and sustainability in the world the General Assembly adopted the Millennium Declaration by United Nations shows that emphasis on environmental issues is increased considerably in this stage. The formation of ecological culture in the process of human nature interaction shows not only its relation with the system, but it means that ecological control system has significant sense in each stage of social development. Moreover, in the process of historical development of humanity, institutional system of ecology is the collection of traditions, customs, holidays and social customs that regulates social groups. Social customs protecting nature and mass media operates as optional union on the basis of ecological necessity and interests. Accordingly, institutions regulated by the state aims at protecting nature and natural environment with the task of organizing and controlling environmental activities.

In conclusion, it can be said that the formation of ecological knowledge, its genesis and evolution covers long historical period and it has peculiar development stages. The accumulated knowledge in historical process, ecological inventions made by scientists and variety of approaches is crucial. Today, as an independent science, the ecology covers many issues and deals with their research.

\section{References}

1. Saidova UG (2008) The history of ecological culture and its stages of development. Abstract of dissertation, Tashkent. P.9-10.

2. Sergeychuk SA (2009) Stages of development of ecology. Minsk. P.23.

3. Worster D (1994) Nature's Economy: A History of Ecological Ideas. Cambridge University Press, pp:12-13.

4. Fraser JG (1980) Golden branch: The study of magic and religion. (3rd edition), Palgrave Macmillan, London. 